\title{
10. RADIOGENIC ISOTOPE RATIOS AND INITIAL SEAFLOOR ALTERATION IN SUBMARINE SEROCKI VOLCANO BASALTS1
}

\author{
Kye-Hun Park ${ }^{2}$ and Hubert Staudigel ${ }^{2,3}$
}

\begin{abstract}
Basalts from ODP Site 648, recovered from Serocki Volcano, a near-axis volcano on the Mid-Atlantic Ridge, are normal mid-ocean ridge basalts, depleted in $\mathrm{K}, \mathrm{Rb}$, and LREE. They have homogeneous source regions with ${ }^{87} \mathrm{Sr} /{ }^{88} \mathrm{Sr}=0.70234-0.70245(\mathrm{~N}=6) ;{ }^{143} \mathrm{Nd} /{ }^{144} \mathrm{Nd}=0.51318-0.51322(\mathrm{~N}=8) ;{ }^{208} \mathrm{~Pb} /{ }^{204} \mathrm{~Pb}=18.53-18.74 ;$ ${ }^{207} \mathrm{~Pb} /{ }^{204} \mathrm{~Pb}=15.40-15.45 ;{ }^{208} \mathrm{~Pb} /{ }^{204} \mathrm{~Pb}=37.83-36.14(\mathrm{~N}=3)$. The recovered materials are generally fresh with minor initial alteration that can be identified petrographically as the minor occurrence of groundmass clays and/or black halos. We have analyzed four separates of black halos, two of them with adjoining fresh bulk rock samples for a comparison of their chemical and isotopic composition. All black halos analyzed occur on or very close to the surfaces of rock fragments, and appear to be of finer groundmass grain size and/or contain less groundmass plagioclase, suggesting a different early cooling history. Two of the black halo samples analyzed were indistinguishable from fresh rock, and two displayed higher $\mathrm{K}, \mathrm{Rb}$, loss-on-ignition, and ${ }^{87} \mathrm{Sr} /{ }^{86} \mathrm{Sr}$ ratios, and lower $\mathrm{K} / \mathrm{Rb}$, chemical variations that suggest higher degree of ocean floor alteration.
\end{abstract}

\section{INTRODUCTION}

Serocki Volcano was formed very recently, probably within the past $10 \mathrm{k} . \mathrm{y}$. , in the neovolcanic zone of the Mid-Atlantic ridge south of the Kane Fracture zone (Detrick et al., 1988; Shipboard Scientific Party, 1988). Serocki Volcano may be considered the latest product of one of several volcanic phases producing the extrusive Layer II of the oceanic crust, and probably will be covered by later extrusive phases until it moves outside the volcanically active region of the Mid-Atlantic ridge. Drilling in such volcanically active portions of the oceanic crust provides the opportunity to study (1) the pristine magmatic composition of the oceanic crust in a stratigraphic context and (2) the alteration processes occurring during between periods of volcanic activity.

Plagioclase phenocrysts at ODP Site 648 and in nearby DSDP Site 396 basalts display complex zoning patterns (normal, reverse, and oscillatory) that were interpreted in terms of repeated mixing and fractionation of distinct mantle-derived magma batches (e.g., Shipboard Scientific Party, 1988; Dungan et al., 1976; Kirkpatrick, 1976; Flower et al., 1976). Such distinct magmas tentatively could be derived from distinct mantle source regions. Identification of heterogeneities is important, because normal mid-ocean ridge basalts (MORB) are generally homogeneous compared to other volcanic rock types, and yet MORB source regions appear to be heterogeneous on a small scale (e.g., Zindler et al., 1984).

Early chemical alteration in the upper oceanic crust may be the result of initial high-temperature, deuteric processes or low temperature seawater-rock interaction. The latter is indicated in minor occurrence of groundmass clay and black halos in Site 648 basalts (Shipboard Scientific Party, 1988). Determining the alteration history of very young submarine volcanics is important for understanding the kinetics of seafloor

\footnotetext{
${ }^{1}$ Detrick, R., Honnorez, J., Bryan, W. B., Juteau, T., et al., 1990. Proc ODP, Sci. Results, 106/109: College Station, TX (Ocean Drilling Program).

2 Lamont-Doherty Geological Observatory of Columbia University. Palisades, NY 10694.

3 Scripps Institution of Oceanography, University of California-San Diego, La Jolla, CA 92093.
}

alteration, which is generally believed to be extremely rapid. The occurrence of black smokers at spreading axes suggests that most chemical fluxes between the ocean crust and the ocean occurs only in the first few tens of thousand years when the crust is still very hot (RISE Project Group, 1980). However, there is ample evidence for alteration processes that last much longer, ranging from $3.5 \mathrm{Ma}$ from magnetic studies (Hall and Robinson, 1979) to $55 \mathrm{Ma}$ from heat flow studies (Anderson et al., 1976).

This paper represents an isotopic and chemical reconnaissance study of the primary igneous composition of Site 648 basalts as well as their alteration.

\section{SAMPLE DESCRIPTION}

All samples analyzed in this paper come from ODP Hole 648B, and thus sample numbers carry the prefixes 106 or 109 for the leg numbers, and 648B for the hole numbers. For convenience, we shall refer to samples omitting these prefixes, only using the identification of the core/section and depth in section.

Basalts from Hole 648B are petrographically quite uniform, with a fine-grained to microcrystalline groundmass, approximately $2 \%$ plagioclase phenocrysts and minor amounts of olivine phenocrysts (Shipboard Scientific Party, 1988). Most prominent alteration characteristics include the occurrence of minor groundmass clay and black halos which are black bands or halos observed in hand specimens of lighter grey rock. Two types of black halos were observed: Type 1 halos are typically associated with fractures, and Type 2 are mostly parallel to chilled margins (Shipboard Scientific Party, 1988). Transitions between these two types were also observed.

Among the bulk rock samples studied, two were identified as petrographically unaltered, whereas Sample 1R-3, 50-52 $\mathrm{cm}$, contains microscopically identifiable clays. Three samples with black halos were studied, by physically separating the black halo material from less altered rock and two black halo separates from one sample. Three black halos studied were located on exterior surfaces or within the rock fragments parallel to chilled margins, and were typically finer grained than the remaining rock indicating relatively rapid cooling compared with interior of the rock fragments. The black halo 
Table 1. Major element analyses of Leg 106 Hole 648B basalts.

\begin{tabular}{llllllllllllr}
\hline \multicolumn{1}{c}{ Sample } & Type & $\mathrm{SiO} 2$ & $\mathrm{TiO} 2$ & $\mathrm{Al} 2 \mathrm{O} 3$ & $\mathrm{Fe} 2 \mathrm{O} 3$ & $\mathrm{MnO}$ & $\mathrm{MgO}$ & $\mathrm{CaO}$ & $\mathrm{Na} 2 \mathrm{O}$ & $\mathrm{K} 2 \mathrm{O}$ & $\mathrm{Sum}$ & $\mathrm{LOI}$ \\
\hline $1 \mathrm{R}-1,0-4 \mathrm{~cm}$ & Bulk Rock & 50.48 & 1.75 & 15.36 & 10.74 & 0.18 & 7.08 & 11.53 & 3.02 & 0.29 & 100.43 & 0.16 \\
$1 \mathrm{R}-3,50-52 \mathrm{~cm}$ & Bulk Rock & 50.50 & 1.66 & 15.22 & 10.81 & 0.18 & 7.60 & 10.93 & 3.04 & 0.18 & 100.12 & 0.29 \\
$6 \mathrm{R}-1,90-93 \mathrm{~cm}$ & Bulk Rock & 50.10 & 1.61 & 15.37 & 10.71 & 0.18 & 7.57 & 10.85 & 2.96 & 0.20 & 99.55 & 0.21 \\
$1 \mathrm{R}-1,78-81 \mathrm{~cm}$ & Black Halo 1 & 50.57 & 1.68 & 15.25 & 10.76 & 0.18 & 7.49 & 11.17 & 2.98 & 0.18 & 100.26 & 0.24 \\
$1 \mathrm{R}-1,78-81 \mathrm{~cm}$ & Black Halo 2 & 50.37 & 1.62 & 15.51 & 10.45 & 0.17 & 7.43 & 10.99 & 3.01 & 0.20 & 99.75 & 0.16 \\
$10 \mathrm{R}-1,2-5 \mathrm{~cm}$ & Black Halo & 50.69 & 1.65 & 14.69 & 11.21 & 0.17 & 7.27 & 10.91 & 2.89 & 0.38 & 99.86 & 0.67 \\
$10 \mathrm{R}-1,2-5 \mathrm{~cm}$ & Inside & 50.92 & 1.67 & 15.56 & 10.46 & 0.18 & 7.56 & 11.24 & 2.92 & 0.25 & 100.76 & -0.01 \\
$18 \mathrm{R}-1,17-21 \mathrm{~cm}$ & Altered Crust & 50.42 & 1.51 & 16.34 & 10.71 & 0.18 & 7.52 & 11.22 & 3.00 & 0.10 & 101.00 & 0.78 \\
$18 \mathrm{R}-1,17-21 \mathrm{~cm}$ & Black Halo & 50.75 & 1.69 & 15.22 & 11.38 & 0.17 & 7.22 & 10.95 & 3.10 & 0.13 & 100.61 & 0.47 \\
$18 \mathrm{R}-1,17-21 \mathrm{~cm}$ & Inside & 50.91 & 1.70 & 15.97 & 10.05 & 0.17 & 6.75 & 11.38 & 3.11 & 0.09 & 100.13 & -0.08 \\
\hline
\end{tabular}

Table 2. Trace element analyses of Leg 106 Hole 648B basalts.

\begin{tabular}{llcccccccccccc}
\hline \multicolumn{1}{c}{ Sample } & Type & $\mathrm{Ba}$ & $\mathrm{Rb}$ & $\mathrm{K}$ & $\mathrm{Sr}$ & $\mathrm{Nd}$ & $\mathrm{Sm}$ & $\mathrm{Cr}$ & $\mathrm{Ni}$ & $\mathrm{V}$ & $\mathrm{Sc}$ & $\mathrm{Zn}$ & $\mathrm{Cu}$ \\
\hline $1 \mathrm{R}-1,0-4 \mathrm{~cm}$ & Bulk Rock & 17.3 & 2.08 & 2181 & 146 & 13.64 & 4.62 & 238 & 86 & 301 & 36 & 78 & 57 \\
$1 \mathrm{R}-3,50-52 \mathrm{~cm}$ & Bulk Rock & 50.3 & 0.96 & 1389 & 138 & 16.04 & 5.48 & 226 & 93 & 275 & 35 & 73 & 52 \\
$6 \mathrm{R}-1,90-93 \mathrm{~cm}$ & Bulk Rock & 25.6 & 0.81 & 1580 & 137 & 13.80 & 4.68 & 245 & 105 & 292 & 36 & 71 & 60 \\
$1 \mathrm{R}-1,78-81 \mathrm{~cm}$ & Black Halo 1 & 46.2 & 1.05 & 1634 & 141 & 12.50 & 4.225 & 242 & 98 & 298 & 35 & 62 & 60 \\
$1 \mathrm{R}-1,78-81 \mathrm{~cm}$ & Black Halo 2 & 54.8 & 0.81 & 1520 & 138 & 12.01 & 4.059 & 229 & 98 & 279 & 34 & 77 & 52 \\
$10 \mathrm{R}-1,2-5 \mathrm{~cm}$ & Black Halo & 18.6 & 6.59 & 2862 & 137 & 11.80 & 3.99 & 243 & 97 & 297 & 34 & 77 & 55 \\
$10 \mathrm{R}-1,2-5 \mathrm{~cm}$ & Inside & 15.1 & 2.83 & 2108 & 141 & 12.44 & n.d. & 244 & 100 & 291 & 36 & 69 & 57 \\
$18 \mathrm{R}-1,17-21 \mathrm{~cm}$ & Altered Crust & 38.9 & n.d. & n.d. & 150 & n.d. & n.d. & 217 & 106 & 260 & 32 & 72 & 94 \\
$18 \mathrm{R}-1,17-21 \mathrm{~cm}$ & Black Halo & 24.3 & 1.61 & 1070 & 144 & 12.21 & 4.128 & 242 & 98 & 302 & 35 & 55 & 64 \\
$18 \mathrm{R}-1,17-21 \mathrm{~cm}$ & Inside & 13.8 & 0.46 & 730 & 141 & 12.83 & 4.31 & 233 & 84 & 291 & 35 & 70 & 50 \\
\hline
\end{tabular}

$\mathrm{K}, \mathrm{Rb}, \mathrm{Nd}$ and $\mathrm{Sm}$ were measured by isotope dilution. $\mathrm{n} . \mathrm{d} .=$ not determined.

of Sample 1R-1, 78-81 cm, was identified as Type 2, whereas Sample 18R-1, 17-21 cm, appeared to be a combination of Type 1 and 2 (Shipboard Scientific Party, 1988). Based on its finer grain size, the black halo of Sample 10R-1, 2-5 cm, is probably of Type 2 . The dark colors in some cases were correlated with fewer and smaller groundmass plagioclase crystals and/or more tachylite than the nearby rock (Sample 1R-1, 78-81 cm; Sample 18R-1, 17-21 cm). The groundmass of black halos contains variable contents of tachylite $(5 \%-20 \%)$, and quench crystals of plagioclase $(<10 \%-20 \%)$ and clinopyroxene $(60 \%-80 \%)$. Groundmass plagioclase in the direct vicinity of the black halo may be aligned forming a localized trachytic texture (Sample 18R-1, 17-21 cm). This alignment may have been caused by laminar flow of melt in vicinity of the early solidified material of the black halo. These textures, suggesting that more rapid quenching initiated the black halo (Type 2), are different from the description of black halos in other submarine lavas from DSDP sites. In published descriptions, black halos typically form concentric zones around fractures in pillows, without any obvious differences in groundmass texture, and thus may be classified as "Type 1" (e.g., Böhlke et al., 1980; Alt and Honnorez, 1984; Laverne and Vivier, 1983).

Sample 1R-1, 78-81 cm, consists mostly of black halo material dispersed in lighter colored material. Two separates of the darker material were prepared, distinguished by contrast in their darkness, but the results of chemical analyses suggest that they are chemically quite similar, and fall in the range of "unaltered" basalts. The best separate of black halo material was obtained from Sample 10R-1, 2-5 cm, with a $3-4-\mathrm{mm}$ thick black halo. Sample $18 \mathrm{R}-1,17-21 \mathrm{~cm}$, was crushed and separated into three fractions, altered crust, black halo, and the least altered interior of the sample.

\section{METHODS}

We have analyzed two groups of samples, three bulk rock samples of different texture and sample depth, and three black halo samples and two corresponding unaltered rock materials. These samples were analyzed for major and trace elements by plasma emission spectrometry (Tables 1 and 2) and for the isotopic ratios of ${ }^{87} \mathrm{Sr} /{ }^{86} \mathrm{Sr}$, ${ }^{143} \mathrm{Nd} /{ }^{144} \mathrm{Nd},{ }^{206} \mathrm{~Pb} /{ }^{204} \mathrm{~Pb},{ }^{207} \mathrm{~Pb} /{ }^{204} \mathrm{~Pb}$, and ${ }^{208} \mathrm{~Pb} /{ }^{204} \mathrm{~Pb}$ (Table 3).

Bulk rock samples were cleaned of surface contamination with $\mathrm{SiC}$ abrasive paper, rinsed with deionized water in an ultrasonic bath, dried with a heat lamp, and ground in a corundum mortar. Black halo separates were prepared by cutting off $2-4-\mathrm{mm}$ slabs with a diamond saw, cleaning the slabs as the bulk rock material above, and crushing with a stainless steel hammer wrapped in clean paper. The darker and typically finer grained black halo material was hand picked, and then ground with a corundum mortar and pestle.

All analytical work was carried out at the Lamont-Doherty Geological Observatory of Columbia University. Major and trace elements were analyzed by induced coupled plasma emission after ignition of powders in a muffle furnace at $950^{\circ} \mathrm{C}$ for $30 \mathrm{~min}$ to oxidize and derive off volatiles, and isotope dilution analyses and $\mathrm{Sr}$ and $\mathrm{Nd}$ isotopic analyses were performed using the methods described in 
Table 3. Isotope analyses of Leg 106 Hole 648B basalts.

\begin{tabular}{llccccc}
\hline \multicolumn{1}{c}{ Sample } & Type & ${ }^{87} \mathrm{Sr} /{ }^{86} \mathrm{Sr}$ & ${ }^{143} \mathrm{Nd} /{ }^{144} \mathrm{Nd}$ & ${ }^{206 \mathrm{~Pb} / 204 \mathrm{~Pb}}$ & ${ }^{207} \mathrm{~Pb} / 204 \mathrm{~Pb}$ & ${ }^{208} \mathrm{~Pb} / 204 \mathrm{~Pb}$ \\
\hline $1 \mathrm{R}-1,0-4 \mathrm{~cm}$ & Bulk Rock & n.d. & $0.513220 \pm 20$ & 18.716 & 15.549 & 38.12 \\
$1 \mathrm{R}-3,50-52 \mathrm{~cm}$ & Bulk Rock & $0.702519 \pm 38$ & $0.513192 \pm 22$ & 18.534 & 15.440 & 37.83 \\
$6 \mathrm{R}-1,90-93 \mathrm{~cm}$ & Bulk Rock & $0.702460 \pm 43$ & $0.513193 \pm 24$ & 18.736 & 15.541 & 38.14 \\
$1 \mathrm{R}-1,78-81 \mathrm{~cm}$ & Black Halo 1 & $0.702495 \pm 32$ & $0.513194 \pm 24$ & n.d. & n.d. & n.d. \\
$1 \mathrm{R}-1,78-81 \mathrm{~cm}$ & Black Halo 2 & $0.702481 \pm 33$ & $0.513182 \pm 18$ & n.d. & n.d. & n.d. \\
$10 \mathrm{R}-1,2-5 \mathrm{~cm}$ & Black Halo & $0.702401 \pm 35$ & n.d. & n.d. & n.d. & n.d. \\
$10 \mathrm{R}-1,2-5 \mathrm{~cm}$ & Inside & $0.702343 \pm 34$ & $0.513189 \pm 24$ & n.d. & n.d. & n.d. \\
$18 \mathrm{R}-1,17-21 \mathrm{~cm}$ & Black Halo & $0.702582 \pm 39$ & $0.513179 \pm 23$ & n.d. & n.d. & n.d. \\
$18 \mathrm{R}-1,17-21 \mathrm{~cm}$ & Inside & $0.702393 \pm 37$ & $0.513189 \pm 23$ & n.d. & n.d. & n.d. \\
& & $0.702373 \pm 43$ & & & & \\
\hline
\end{tabular}

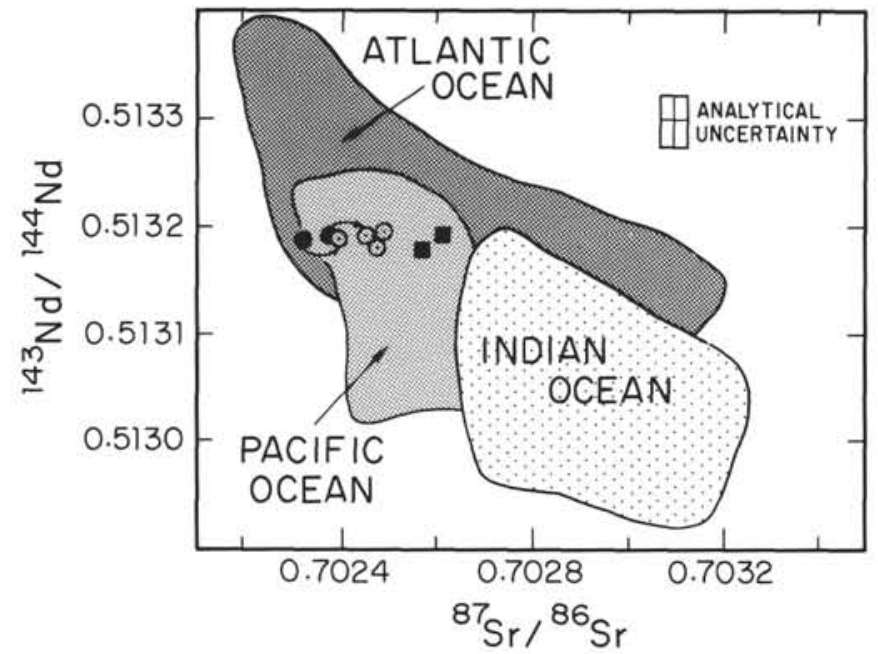

Figure 1. ${ }^{143} \mathrm{Nd} /{ }^{144} \mathrm{Nd}$ vs. ${ }^{87} \mathrm{Sr} /{ }^{86} \mathrm{Sr}$ for bulk rock analyses (solid squares) and black halo and fresh rock pairs (open and filled circles, respectively) from ODP Hole $648 \mathrm{~B}$, in comparison to the data distribution of mid-ocean ridge basalts from the Indian, Pacific, and Atlantic Oceans (after compilation in Klein et al., 1988).

Zindler et al. (1984). $\mathrm{Pb}$ isotopic analyses broadly followed the techniques of Tilton (1973).

\section{RESULTS}

Major and trace element and isotopic data for all analyzed samples are within the range of normal MORB, but signs of low temperature alteration are apparent in some samples (Table 1-3). Particularly diagnostic for MORB are the low abundances of $\mathrm{K}_{2} \mathrm{O}, \mathrm{Rb}$, incompatible elements and REE, and low $\mathrm{Sm} / \mathrm{Nd}$ ratios indicating LREE-depleted rare earth element patterns. Major and trace element characteristics of basalts from Site 648 , together with their petrographic characteristics suggest complex magma mixing and fractionation processes that are discussed in more detail elsewhere (e.g., Shipboard Scientific Party, 1988; Loubet et al., this volume; and Bryan et al., this volume).

In Figure 1, we have plotted the ${ }^{143} \mathrm{Nd} /{ }^{144} \mathrm{Nd}$ vs. ${ }^{87} \mathrm{Sr} /{ }^{86} \mathrm{Sr}$ for all samples analyzed, together with the fields for the Atlantic, Pacific, and Indian Oceans from a compilation by Klein et al. (1988). The samples fall within the Atlantic Ocean field, with no significant variation in ${ }^{143} \mathrm{Nd} /{ }^{144} \mathrm{Nd}$, but substantial spread in ${ }^{87} \mathrm{Sr} /{ }^{86} \mathrm{Sr}$. Because samples that were considered

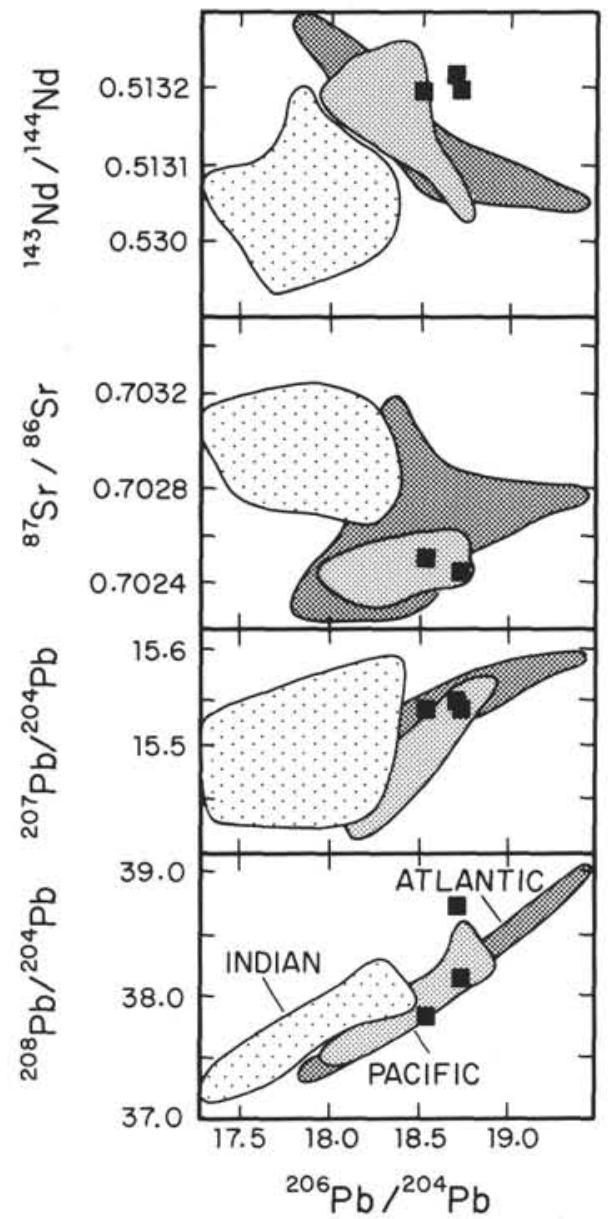

Figure 2. ${ }^{143} \mathrm{Nd} /{ }^{144} \mathrm{Nd},{ }^{87} \mathrm{Sr} /{ }^{86} \mathrm{Sr},{ }^{207} \mathrm{~Pb} /{ }^{204} \mathrm{~Pb}$, and ${ }^{208} \mathrm{~Pb} /{ }^{204} \mathrm{~Pb}$ vs. ${ }^{206 \mathrm{~Pb}} /{ }^{204} \mathrm{~Pb}$ for bulk rock analyses from ODP Hole $648 \mathrm{~B}$ in comparison to the data distribution of mid-ocean ridge basalts from the Indian, Pacific, and Atlantic Oceans (after compilation in Klein et al., 1988).

"unaltered" on the basis of their petrography and major element geochemistry (the "fresh rock" separate from interior of Sample 10R-1, 2-5 cm, and Sample 18R-1, 17-21 cm, and the bulk rock Sample 6R-1, 90-93 cm) fall in a narrow range of ${ }^{87} \mathrm{Sr} /{ }^{86} \mathrm{Sr}$ between 0.70234 and 0.70246 , we suspect that the observed spread in ${ }^{87} \mathrm{Sr} /{ }^{86} \mathrm{Sr}$ is probably caused by seafloor alteration which shall be discussed in more detail 


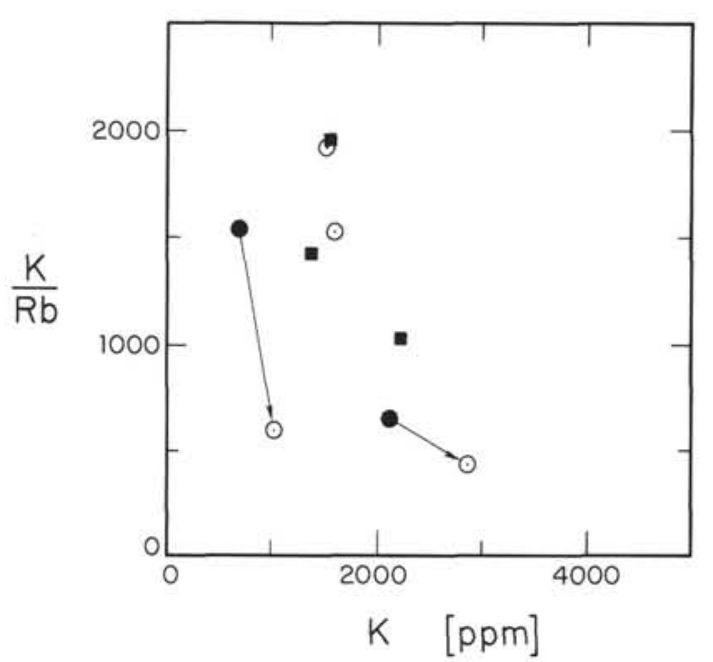

Figure $3 . \mathrm{K} / \mathrm{Rb}$ vs. $\mathrm{K}$ for bulk rocks (solid squares) and black halo and fresh rock pairs (open and filled circles, respectively).

below. In Figure 2, we have plotted $\mathrm{Sr}, \mathrm{Nd}$, and $\mathrm{Pb}$ isotope data vs. ${ }^{206} \mathrm{~Pb} / 204 \mathrm{~Pb}$. Two of the data points in the ${ }^{143} \mathrm{Nd} /{ }^{144} \mathrm{Nd}$ vs. ${ }^{206} \mathrm{~Pb} /{ }^{204} \mathrm{~Pb}$ fall slightly outside the field for MORB data, but all data are generally similar to "normal" MORB from the Pacific and Atlantic Oceans. On a more regional scale, $\mathrm{Sr}$ and $\mathrm{Nd}$ isotopic ratios are identical to other published data from this region in the Atlantic at approximately $25^{\circ} \mathrm{N}$, while the $\mathrm{Pb}$ isotope ratios tend to be slightly higher in ${ }^{206} \mathrm{~Pb} /{ }^{204} \mathrm{~Pb}$ and ${ }^{208} \mathrm{~Pb} /{ }^{204} \mathrm{~Pb}$ and lower in ${ }^{207} \mathrm{~Pb} /{ }^{204} \mathrm{~Pb}$ (e.g., Ito et al., 1987).

Despite the fact that alteration is petrographically minor and that all isotope ratios and element abundances are compatible to the values of unaltered MORB, the effects of low temperature alteration are apparent from major elements, elemental ratios, and from ${ }^{87} \mathrm{Sr} /{ }^{86} \mathrm{Sr}$ isotope ratios. Samples that were identified as altered from their petrographic appearance (black halos and sample 1R-3, 50-52 cm) show up to a fourfold increase in $\mathrm{K}$ concentrations relative to the lowest values (Table 3). The range in $\mathrm{Rb}$ concentrations is even larger; from $0.46 \mathrm{ppm}$ in the least altered sample to 6.59 in the black halo of Sample 10R-1, 2-5 cm. The largest spread was observed in $\mathrm{K} / \mathrm{Rb}$ ratios, spanning a range identical to that of $\mathrm{K} / \mathrm{Rb}$ ratios in palagonites and smectites from 118-Ma-old DSDP Holes 417A, 417D, and 418A (Figs. 3 and 4; Staudigel et al., 1981). Ba also shows a significant range from 13 to 50 ppm, with the lowest concentrations generally in the freshest samples. Altered samples also show weight losses during ignition, while fresh rocks commonly display a weight gain. Weight gain during ignition suggests that the weight loss from volatile outgassing (mostly $\mathrm{H}_{2} \mathrm{O}$ and $\mathrm{S}$ ) is insufficient to balance the gain from oxidation. Therefore, black halos are more oxidized and/or contain higher amounts of $\mathrm{H}_{2} \mathrm{O}$ and $\mathrm{S}$, or sulfur oxides. The former two are typical effects of hydrous basalt alteration.

We have plotted our data in a $\mathrm{K} / \mathrm{Rb}$ vs. K diagram (Fig. 3) and $\mathrm{a}^{87} \mathrm{Sr} /{ }^{86} \mathrm{Sr}$ vs. $\mathrm{K} / \mathrm{Rb}$ diagram (Fig. 4). Low temperature submarine alteration of basalt typically involves an uptake of $\mathrm{K}$ and an increase in ${ }^{87} \mathrm{Sr} /{ }^{86} \mathrm{Sr}$ (e.g., Hart, 1969; Hart and Nalwalk, 1970). K/Rb ratios can increase or decrease, depending on the type of alteration (Staudigel et al., 1981). Addition of smectite tends to decrease the $\mathrm{K} / \mathrm{Rb}$ ratio, and addition of seawater alkalies increases the $\mathrm{K} / \mathrm{Rb}$ ratio. The $\mathrm{K} / \mathrm{Rb}$ and $\mathrm{K}$ display a weak negative array that is illustrated by the changes in $\mathrm{K}$ and $\mathrm{K} / \mathrm{Rb}$ observed in the fresh rock/black halo pairs (Fig. 3). The decrease in $\mathrm{K} / \mathrm{Rb}$, combined with an increase of $\mathrm{K}$ is typical of formation of palagonite or smectite.

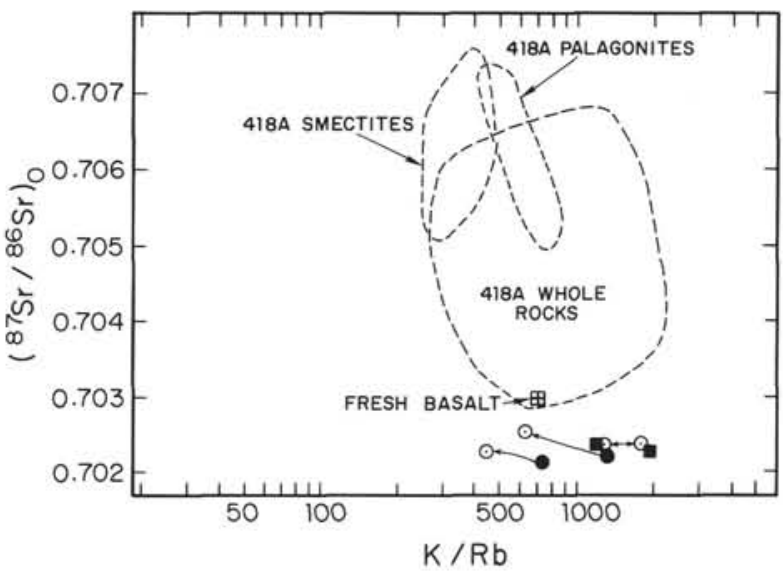

Figure $4 .{ }^{87} \mathrm{Sr} /{ }^{86} \mathrm{Sr}$ vs. K/Rb for bulk rocks (solid squares) and black halo and fresh rock pairs (open and filled circles, respectively). For comparison, the dashed lines depict the field for DSDP Hole 417A, 417D, and 418A bulk rocks, glasses, palagonites, and smectites, after Staudigel et al. (1981).

Figure 4 compares our ${ }^{87} \mathrm{Sr} /{ }^{86} \mathrm{Sr}$ and $\mathrm{K} / \mathrm{Rb}$ data with secondary phases and bulk rocks from 118-Ma-old DSDP Sites 417 and 418. It is apparent that the range of $\mathrm{K} / \mathrm{Rb}$ ratios of Hole $648 \mathrm{~B}$ basalts is almost as large as the smectite, palagonite, and bulk rock data from the 118-Ma-old DSDP Sites 417 and 418, but the absolute value and the range of Site $648{ }^{87} \mathrm{Sr}{ }^{86} \mathrm{Sr}$ is lower and much smaller, respectively. The lower Site $648^{87} \mathrm{Sr} /{ }^{86} \mathrm{Sr}$ probably reflects differences in source compositions between these sites because glass and leached bulk rock data consistently point at a ${ }^{87} \mathrm{Sr} /{ }^{86} \mathrm{Sr}=0.7029$ for Site 417 and 418 (e.g., Staudigel et al., 1981). This comparison shows that the $\mathrm{K} / \mathrm{Rb}$ ratios are more sensitive to initial seafloor alteration than the ${ }^{87} \mathrm{Sr} /{ }^{86} \mathrm{Sr}$.

\section{DISCUSSION}

The data are similar to other data from this section of the Mid-Atlantic Ridge at $24^{\circ}-25^{\circ} \mathrm{N}$ and suggest that all basalts analyzed were derived from a relatively homogeneous source region that is typical of Atlantic/Pacific Ocean MORB. The chemical and isotopic homogeneity contrasts with the complex zoning behavior commonly found in plagioclase phenocrysts from this site and the nearby Site 396 (e.g., Dungan et al., 1976). For this reason, individual magma batches inferred from the plagioclase zoning must either come from a homogeneous source region or they are efficiently homogenized during mixing.

Two conclusions may be drawn from the alteration-related chemical and isotopic variations observed in this study: (1) $\mathrm{K}$ and $\mathrm{Rb}$ abundances and ratios are very sensitive indicators of initial alteration, and (2) initial low temperature seafloor alteration is a relatively slow process.

The more sensitive behavior of $\mathrm{K}$ and $\mathrm{Rb}$, in comparison to $\mathrm{Sr}$, is probably best explained by the preferred partitioning of $K / R b$ in unstable phases of a bulk rock (interstitial material, tachylite) while a significant fraction of the $\mathrm{Sr}$ resides in plagioclase that is not as easily attacked by chemical alteration. Furthermore, the distribution of $\mathrm{K} / \mathrm{Rb}$ and $\mathrm{Sr}$ in basalt and seawater is such that much higher water volumes are needed to alter the concentration or isotopic composition of $\mathrm{Sr}$.

The relatively unaltered nature of Hole $648 \mathrm{~B}$ basalts is not an unexpected result. Bulk rock analyses from 3.5-Ma-old Site 332 suggested that hydration was still not completed when compared to a "saturated" altered basalt from 120-Ma-old Site 418A (Staudigel et al., 1981). Thus, the kinetics of pervasive alteration must be very slow at low temperatures. 
As suggested above, the Type 2 black halos analyzed in this study are distinct from the black halos found as concentric zones in vicinity of veins (Alt and Honnorez, 1984), because they appear to be more rapidly quenched than the neighboring rock. Such quench zones may indicate the quenched margin of pillow lavas or other submarine flows, or they may form at the tip of a cooling fracture propagating into the still partially molten interior of a pillow. Quench zones on the margins of pillows that extend into the pillow along fractures are quite common in pillow breccias (Staudigel and Schmincke, 1984). Such more rapid cooling increases the modal proportion of interstitial glass and tachylite and thus the proportion of a rock that is unstable in contact with seawater. The darker color of some black halos is correlated with lower abundance of groundmass feldspar indicating rapid cooling. The location of the Type 2 black halos on fragment surfaces also provides more extensive exposure to seawater, further enhancing the probability of alteration. The variations in $\mathrm{K}$ and $\mathrm{K} / \mathrm{Rb}$ in black halos are typical of low temperature, seafloor alteration of pillow margins characterized by the formation of smectites or palagonites. Thus, alteration of Type 2 black halos is indistinguishable from alteration occurring in pillow margins, and possibly may be interpreted as such.

\section{ACKNOWLEDGMENTS}

This work was supported by the U.S. Science Advisory Committee (to H.S.) and the National Science Foundation (OCE 87-1 1798; to A. Zindler and H.S.). We thank J. Rubenstone, A. P. LeHuray, J. Ludden, and an anonymous reviewer for their reviews and constructive suggestions. We would also like to thank Charles Langmuir, Dave Christie, and Bushra Hussaini for showing us the way and letting us use the plasma machine.

\section{REFERENCES}

Alt, J. C., and Honnorez, J., 1984, Alteration of the upper oceanic crust, DSDP site 417: Mineralogy and chemistry. Contrib. Mineral. Petrol., 87:149-169.

Anderson, R., Hobart, M. A., and Langseth, M., 1976, Geothermal convection through oceanic crust and sediments in the Indian Ocean. Science, 204:828-832.

Böhlke, J. K., Honnorez, J. and Honnorez-Guerstein, B.-M., 1980, Alteration of basalts from Site 396B, DSDP: Petrographic and mineralogic studies. Contrib. Mineral. Petrol., 73:341-364.

Detrick, R., Honnorez, J., Bryan, W. B., Juteau, T., et al., 1989. Proc. ODP, Init. Repts., 106/109: College Station, TX (Ocean Drilling Program).

Dungan, M. A., Rhodes, J. M., Long, P. E., Blanchard, D. P., Brannon, J. C., and Rodgers, K. V., 1976, The petrology and geochem- istry of basalts from Site 396, Legs 45 and 46 of the Deep Sea Drilling Project. In Dmitriev, L., Heirtzler, J., et al., Init. Repts. DSDP, 46: Washington (U.S. Govt. Printing Office), 89-113.

Flower, M.F.J., Ohnmacht, W., Schmincke, H.-U., Gibson, I. L., Robinson, P. T., Parker, R., 1976, Petrology and geochemistry of basalts from Hole 396B Leg 46. In Dmitriev, L., Heirtzler, J., et al., Init. Repts. DSDP, 46: Washington (U.S. Govt. Printing Office), 179-213.

Hall, J. M., and Robinson, P. T., 1979, Deep crustal drilling in the North Atlantic Ocean. Science, 204:573-586.

Hart, S. R., 1969, K, Rb, Cs contents and K/Rb, K/Cs ratios of fresh and altered submarine basalts. Earth Planet. Sci. Lett., 6:295-303.

Hart, S. R., and Nalwalk, A. J., 1970, K, Rb, Cs, and Sr relationships in submarine basalts from the Puerto Rico trench. Geochim. Cosmochim. Acta, 34:145-155.

Ito, E., White, W. M., and Göpel, C., 1987. The O, Sr, Nd, and Pb isotope geochemistry of MORB. Chem. Geology, 62:157-176.

Kirkpatrick, R. J. 1976, Petrology of Basalts: Hole 396B, DSDP Leg 46. In Dmitriev, L., Heirtzler, J., et al., Init. Repts. DSDP, 46: Washington (U.S. Govt. Printing Office), 165-178.

Klein, E. M., Langmuir, C. H., Zindler, A., Staudigel, H., and Hameline, B., 1988, Isotope evidence of a mantle convection boundary at the Australian-Antarctic Discordance. Nature, 333: $623-629$.

Laverne, C., and Vivier, G., 1983, Petrographic and chemical study of basement from the Galapagos spreading center, Leg 70. In Honnorez, J., Von Herzen, R. P., et al., Init. Repts. DSDP, 70: Washington (U.S. Govt. Printing Office), 375-390.

RISE Project Group, 1980, East Pacific Rise: Hot springs and geophysical experiments. Science, 207:1421-1433.

Shipboard Scientific Party, 1988. Site 648, In Detrick, R. S., Honnorez, J., Bryan, W. B., Juteau, T., et al., 1989. Proc. ODP, Init. Repts., 106/109: College Station, TX (Ocean Drilling Program), 35-134.

Staudigel, H., and Schmincke, H.-U., 1984, The Pliocene seamount series of La Palma/Canary Islands. J. Geophys. Res., 89:1119511215.

Staudigel, H., Hart, S. R., and Richardson, S. H., 1981, Alteration of the oceanic crust: processes and timing. Earth Planet. Sci. Lett., 52:311-327.

Tilton, G. R., 1973, Isotopic lead ages of chondritic meteorites. Earth Planet. Sci. Lett., 19:321-329.

Zindler, A., Staudigel, H., and Batiza, R., 1984, Isotope and trace element geochemistry of young Pacific seamounts: Implications for the scale of upper mantle heterogeneity. Earth Planet. Sci. Lett., 70:175-195.

Date of initial receipt: 30 May 1988

Date of acceptance: 1 May 1989

Ms 106/109B-134 